\title{
ZS Research Square \\ Composition And Key-Influencing Factors of Bacterial Communities Active In Sulfur Cycling of Soda Lake Sediments
}

\section{Xiangyuan Li}

Institute of Process Engineering, Chinese Academy of Sciences

Maohua Yang ( $\nabla$ mhyang@ipe.ac.cn )

Institute of Process Engineering, Chinese Academy of Sciences https://orcid.org/0000-0002-4410-0949

\section{Tingzhen Mu}

Institute of Process Engineering, Chinese Academy of Sciences

\section{Delu Miao}

Institute of Process Engineering, Chinese Academy of Sciences

\section{Jinlong Liu}

Hebei University of Science and Technology

Jianmin Xing

Institute of Process Engineering, Chinese Academy of Sciences

\section{Research Article}

Keywords: Soda lake, sulfur cycle, haloalkaliphiles, sulfide-oxidizing bacteria, sulfate-reducing bacteria

Posted Date: December 16th, 2021

DOI: https://doi.org/10.21203/rs.3.rs-1133758/v1

License: (c) (i) This work is licensed under a Creative Commons Attribution 4.0 International License. Read Full License 


\section{Abstract}

Bacteria are important participants in sulfur cycle of the extremely haloalkaline environment, e.g. soda lakes. The effects of physicochemical factors on the composition of sulfide-oxidizing bacteria (SOB) and sulfate-reducing bacteria (SRB) in soda lakes have remained elusive. Here, we surveyed the communities structure of total bacteria, SOB and SRB based on 16S rRNA, soxB and $d s r B$ gene sequencing, respectively, in five soda lakes with different physicochemical factors. The results showed that the dominant bacteria in soda lakes sediments belonged to the phyla Proteobacteria, Bacteroidetes, Halanaerobiaeota, Firmicutes and Actinobacteria. SOB and SRB were widely distributed in lakes with different physicochemical characteristics $\$ and the community composition were different . In general, salinity and inorganic nitrogen sources $\left(\mathrm{NH}_{4}{ }^{+}-\mathrm{N}, \mathrm{NO}_{3}{ }^{-} \mathrm{N}\right)$ were the most significant factors. Specifically, the communities of SOB, mainly including Thioalkalivibrio, Burkholderia, Paracoccus, Bradyrhizobium, and Hydrogenophaga genera, were remarkably influenced by the levels of $\mathrm{NH}_{4}{ }^{+}-\mathrm{N}$ and salinity. Yet, for SRB communities, including Desulfurivibrio, Candidatus Electrothrix, Desulfonatronospira, Desulfonatronum, Desulfonatronovibrio, Desulfonatronobacter and so on, the most significant determinants were salinity and $\mathrm{NO}_{3}{ }^{-}-\mathrm{N}$. Besides, Rhodoplanes played a significant role in the interaction between SOB and SRB. From our results, the knowledge regarding the community structures of SOB and SRB in extremely haloalkaline environment was extended.

\section{Introduction}

Soda lake is a unique ecosystem with both high salinity and high $\mathrm{pH}$, in which the total salt concentration exceeds $50 \mathrm{~g} /$ L, and the pH value can reach 10 (Schagerl and Renaut 2016; Furian et al. 2013). Despite these double extreme conditions, most lakes have high productivity and contain fully functional microbial systems. Due to the presence of high concentration of inorganic sulfur compounds, microbial sulfur cycle is one of the most active cycles in soda lake, which provides sufficient energy for microorganisms to cope with costly life at double extreme conditions (Sorokin, 2017; Sorokin et al., 2015).

Haloalkalophilic sulfur oxidizing bacteria (SOB) participate in the oxidation part of the sulfur cycle in soda lake. The majority of detected SOB in soda lakes belong to Gammaproteobacteria and Alphaproteobacteria classes, which can be divided into three categories: chemoautotrophic (colorless) sulfur bacteria, purple sulfur bacteria, and purple non-sulfur bacteria (Berben, 2019). Up to now, four genera of chemolithotrophic SOB have been found in soda lakes:

Thioalkalimicrobium, Thioalkalispira, Thioalkalivibrio and Thioalkalibacter. They can utilize reduced sulfur compounds, such as sulfide, polysulfide, thiosulfate, polythionates, and elemental sulfur as e-donor (Sorokin, 2017; Sorokin et al. 2015). The purple sulfur bacteria mainly include canoxygenic phototrophs in soda lakes, such as the genera Ecthothiorhodospira, Halorhodospira, Thiorhodospira, Thioalkalicoccus, and Ectothiorhodosinus (Gorlenko, 2007). The sulfate-reducing bacteria (SRB) found in the anoxic layer of soda lakes sediments belong to the Deltaproteobacteria class (Sorokin, 2017; Sorokin et al. 2015). Members of the deltaproteobacterial haloalkaliphilic genera Desulfonatronum, Desulfonatronovibrio, Desulfonatronospira and Desulfohalophilus have been detected in soda lakes. They can grow either as typical SRB by oxidizing hydrogen, formate or small organic molecules using sulfate, thiosulfate or sulfite as electron acceptor, or by thiosulfate or sulfite disproportionation (Sorokin et al. 2011).

Previous studies have shown that the structure of SOB and SRB communities could be affected by the physicochemical factors of the environment. For instance, Edwardson et al. compared the composition of microbial communities along the redox gradient of Mono Lake, California, USA at five depths. They found that the prokaryotic community was dominated by bacteria and the community diversity increased with depth (Edwardson and Hollibaugh, 2018). In petroleum reservoirs, the SRB and SOB communities were closely associated with temperature of a reservoir, $\mathrm{pH}$ of formation brine, and sulfate concentration (Tian et al. 2017). And several scholars demonstrated that environmental 
parameters, such as depth, dissolved inorganic nitrogen concentrations and the sedimentary dynamic environment, can significantly influence the community structures of total bacteria, SOB and SRB in sea (Zhang et al. 2017). However, the effects of physicochemical characteristics on the composition of SOB and SRB in haloalkaline environment have remained elusive. Therefore, the present study aimed to assess the diversity and structures of bacteria associated with sulfur cycle in soda lakes with different physicochemical characteristics in Inner Mongolia, China (Fig. 1).

Due to the high phylogenetic diversity of SOB and SRB, we used high-throughput sequencing of 16s rRNA gene coupled to clone libraries of the functional genes to determine the community structures of SOB and SRB. The soxB gene, encoding a key enzyme of the Sox pathway sulfate thiohydrolase, had been detected in sulfur oxidizers irrespective of the pathway, and thus it was selected as the biomarker of SOB in our study (Zhang et al. 2017; Meyer et al. 2007). The $d s / B$ gene is the main subunit of isomerization (bi) sulfite reductase (DsrB) which is highly essential for the reduction of sulfite to sulfide. This gene had been used as a phylogenetic marker for SRB identification (Giloteaux et al. 2013; Gao et al. 2015). In this study, the combination of $16 \mathrm{~S}$ rRNA gene and functional genes sequencing would improve our ability to analyze these microbial populations in detail.

\section{Materials And Methods}

\section{Sites description and sampling}

The sampling sites were located in Ordos, Inner Mongolia Autonomous Region, China. This region has a temperate continental climate with an annual average temperature of $5.3-8.7^{\circ} \mathrm{C}$. The annual rainfall in this region is $170-450 \mathrm{~mm}$, which primarily falls from July to September. The evaporation is remarkable, with annual evaporation of 2000-3000 mm (Xu et al. 2010). The details of five sampling sites are as follows: soda lake A (Haole Baoji Nao; E108 ${ }^{\circ} 54^{\prime} 07^{\prime \prime}$, N3873'49"), soda lake B (Xiaohu; E10852'69", N39³9'83"), soda lake C (Bayin Naoer; E10846'30", N39³8'86"), soda lake D (Hama Rige Tainao Er; Salt Pond No. 1, E10803'16", N3909'07"), and soda lake E (Hama Rige Tainao Er; Salt Pond No. 2, E108 $\left.03^{\prime} 16^{\prime \prime}, \mathrm{N} 39^{\circ} 09^{\prime} 07^{\prime \prime}\right)$. Sediment samples $\left(50 \mathrm{~cm}^{3}\right)$ of five soda lakes were collected at July 25,2019 . For each lake, three sediment samples (depth of $0-10 \mathrm{~cm}$ ) were taken, as shown in Fig. $1 \mathrm{~A}$. All the samples were placed in sterile plastic bags and were transported to the laboratory in a portable ice bag at $4{ }^{\circ} \mathrm{C}$. In the laboratory, the sediment samples were divided into two parts: one part was for subsequent microbial DNA extraction, and the other was for physicochemical tests (Rastogi et al. 2009).

\section{Chemical Analyses Of Soda Lake Sediments}

To measure the sediment $\mathrm{pH}$ and conductivity, the sediment was suspended in ultrapure water at a ratio of 1:5 ( $\mathrm{w} / \mathrm{w}$ ) and then the suspension was vortexed. Following the centrifugation at $21,500 \times \mathrm{g}$ for $1 \mathrm{~min}$ at $4{ }^{\circ} \mathrm{C}, \mathrm{pH}$ and electrical conductivity of the supernatant was measured with a multiparameter probe (Mettler Toledo Delta 320, Switzerland). The concentrations of $\mathrm{NO}_{3}{ }^{-}$and $\mathrm{NH}_{4}{ }^{+}$were analyzed by spectrophotometry (Perkin-Elmer Lambda 35, USA) (Sheibley et al. 2003). The concentrations of $\mathrm{SO}_{4}{ }^{2-}, \mathrm{Cl}^{-}$and $\mathrm{Na}^{+}$were determined by ion chromatography (DIONEX ICS-1000) using a cation-exchange column (DIONEX ICs-1000) and an anion-exchange column (Shim-Pack IC-C3). The sediment was dried at $105^{\circ} \mathrm{C}$ until the weight became constant to calculate the moisture concentration (MC). After that, the dried sediment was heated in a muffle furnace at $550^{\circ} \mathrm{C}$ for $5 \mathrm{~h}$ to measure the total organic matter (TOM) (Santisteban et al. 2004). All analyses were performed in triplicate, and the mean values with standard deviations (SD) were given.

\section{Genome extraction and high-throughput sequencing of 16S rRNA, soxB, and dsrB genes}


Total DNA was extracted from sediment samples using FastDNA® SPIN Kit for Soil (MP Biomedicals, Santa Ana, CA, USA) according to manufacturer's instructions. The DNA extract was checked on $1 \%$ agarose gel, while concentration and purity of DNA were detected with NanoDrop 2000 UV-vis spectrophotometer (Thermo Fisher Scientific, Waltham, MA, USA). V3-V4 hypervariable region of $16 \mathrm{~S}$ rRNA, soxB gene and $d s r B$ gene were amplified by an ABI GeneAmp® 9700 PCR thermocycler ( $A B I, C A, U S A)$. The primer sequences were shown in Table 1 (Tian et al. 2017). The PCR product was extracted from $2 \%$ agarose gel, and then purified using the AxyPrep DNA Gel Extraction Kit (Axygen Biosciences, Union City, CA, USA) according to the manufacturer's instructions and quantified by using Quantus ${ }^{\text {TM }}$ Fluorometer (Promega Corp., Madison, WI, USA). Purified amplicons were pooled in an equimolar and paired-end sequenced on an Illumina MiSeq PE300 platform (Illumina, San Diego, CA, USA) according to the standard protocols provided by Majorbio BioPharm Technology Co. Ltd. (Shanghai, China). The raw reads were deposited into the NCBI Sequence Read Archive (SRA) database (Accession Number: PRJNA678019).

Table 1

Primer sequences used for PCR

\begin{tabular}{|ll|}
\hline Gene & Primer sequence \\
\hline 16S rRNA & 338F: (5'-ACTCCTACGGGAGGCAGCAG-3') \\
& 806R: (5'- GGACTACHVGGGTWTCTAAT-3') \\
soxB & 710F:(5'-ATCGGYCAGGCYTTYCCSTA-3') \\
& 1184R:(5'-MAVGTGCCGTTGAARTTGC-3') \\
dsr'B & DSRp2060F :(5'-CAACATCGTYCAYACCCAGGG-3') \\
& DSR4R:(5'-GTGTAGCAGTTACCGCA-3') \\
\hline
\end{tabular}

\section{Sequence analysis of the $16 \mathrm{~S}$ rRNA, dsrB, and soxB genes}

Microbiome bioinformatics were performed with QIIME2 2019.4C (Bokulich et al. 2018) with slight modification according to the official tutorials (https://docs.qiime2.org/2019.4/tutorials/). Briefly, raw sequence data were demultiplexed using the demux plugin following by primers cutting with cutadapt plugin (Martin, 2011). Sequences were then merged, quality filtered and dereplicated using functions of fastq_mergepairs, fastq_filter and derep fullength in Vsearch plugen. All the unique sequences were then clustered at $98 \%$ (via cluster_size) followed by chimera removing (via uchime_denovo). At last, the non_chimera sequences were re_clustered at $97 \%$ to generate OTU representive sequences and OTU table. Non-singleton amplicon sequence variants (OTUs) were aligned with mafft (Katoh et al. 2002) and used to construct a phylogeny with fasttree2 (Price et al. 2009). Alpha-diversity metrics Chao1, Shannon, Simpson, Pielou's evenness and Good's coverage were estimated using the diversity plugin. SOB and SRB samples were rarefied to 2293 and 707 sequences per sample, respectively. Taxonomy was assigned to OTUs using the classifysklearn naïve Bayes taxonomy classifier in feature-classifier plugin (Bokulich et al. 2018) against the SILVA Release 132 and NCBI Database (Koljalg et al. 2013).

\section{Bioinformatics And Statistical Analysis}

Sequence data analyses were mainly performed using QIIME2 and R packages (v3.2.0). The taxonomy compositions and abundances were visualized using MEGAN (Koljalg et al. 2013) and GraPhIAn software (Asnicar et al. 2015). The abundance comparison among groups at the phylum and genus levels was performed by Metastats analysis (White et al. 2009) and then visualized as a histogram. R programming language (Ihaka and Gentleman, 1996) was used to analyze and draw Heatmap graphs, and Gephi 0.9.2 (Bastian et al. 2009) was employed to analyze and draw microbial 


\section{Results}

\section{Physicochemical characteristics of five soda lakes}

The physicochemical parameters of the samples collected from soda lakes were significantly different (Table 2). The salinity $\left(\mathrm{Na}^{+}\right)$of the samples ranged from $7.99 \mathrm{~g} / \mathrm{L}$ to $68.45 \mathrm{~g} / \mathrm{L}$. The salinity $\left(\mathrm{Na}^{+}\right)$was as high as $60.00 \mathrm{~g} / \mathrm{L}$ and 68.45 $\mathrm{g} / \mathrm{L}$ in samples of lakes $B$ and $D$, respectively, while it was medium in samples of lakes $C$ and $E$, and very low in lake $A$ $(7.99 \mathrm{~g} / \mathrm{L})$, which were consistent with the conductivity data of water samples. In the samples, $\mathrm{CO}_{3}{ }^{2-}, \mathrm{Cl}^{-}$and $\mathrm{SO}_{4}{ }^{2-}$ were the main anions, and their concentrations were positively correlated with salinity $\left(\mathrm{Na}^{+}\right)$, which were significantly higher than those of freshwater lakes. The color of water samples of lakes B and D was pink, and other lakes were colorless. The pink lake could be explained by dense blooms of halophilic microorganism, which synthesized lots of carotenoid to adapt to the environment of low dissolved oxygen and high light intensity (Grant and Sorokin, 2011). 
Table 2

Physicochemical parameters of sediment samples from five soda lakes

\begin{tabular}{|c|c|c|c|c|c|c|c|c|}
\hline Sample & $\mathrm{pH}$ & $\mathrm{SO}_{4}{ }^{2-}(\mathrm{g} / \mathrm{L})$ & $\mathrm{Cl}^{-}(\mathrm{g} / \mathrm{L})$ & $\mathrm{Na}^{+}(\mathrm{g} / \mathrm{L})$ & $\begin{array}{l}\mathrm{NO}_{3}{ }^{-}- \\
\mathrm{N}(\mathrm{mg} / \mathrm{kg})\end{array}$ & $\begin{array}{l}\mathrm{NH}_{4}^{+}- \\
\mathrm{N}(\mathrm{mg} / \mathrm{kg})\end{array}$ & MC(\%) & TOM(mg/kg) \\
\hline A1 & $9.22( \pm 0.03)$ & $\begin{array}{l}0.54 \\
( \pm 0.01)\end{array}$ & $\begin{array}{l}1.63 \\
( \pm 0.08)\end{array}$ & $\begin{array}{l}8.28 \\
( \pm 0.06)\end{array}$ & $\begin{array}{l}2.85 \\
( \pm 0.10)\end{array}$ & $\begin{array}{l}15.14 \\
( \pm 0.09)\end{array}$ & $\begin{array}{l}25.21 \\
( \pm 0.06)\end{array}$ & $\begin{array}{l}40.92 \\
( \pm 0.16)\end{array}$ \\
\hline A2 & $9.63( \pm 0.12)$ & $\begin{array}{l}0.68 \\
( \pm 0.03)\end{array}$ & $\begin{array}{l}1.36 \\
( \pm 0.18)\end{array}$ & $\begin{array}{l}8.00 \\
( \pm 0.22)\end{array}$ & $\begin{array}{l}2.17 \\
( \pm 0.03)\end{array}$ & $\begin{array}{l}6.79 \\
( \pm 0.11)\end{array}$ & $\begin{array}{l}14.40 \\
( \pm 0.06)\end{array}$ & $9.86( \pm 0.11)$ \\
\hline A3 & $9.33( \pm 0.33)$ & $\begin{array}{l}0.61 \\
( \pm 0.01)\end{array}$ & $\begin{array}{l}1.70 \\
( \pm 0.10)\end{array}$ & $\begin{array}{l}7.99 \\
( \pm 0.09)\end{array}$ & $\begin{array}{l}8.40 \\
( \pm 0.09)\end{array}$ & $\begin{array}{l}19.28 \\
( \pm 0.14)\end{array}$ & $\begin{array}{l}23.50 \\
( \pm 0.11)\end{array}$ & $\begin{array}{l}14.28 \\
( \pm 0.03)\end{array}$ \\
\hline B1 & $9.69( \pm 0.23)$ & $\begin{array}{l}11.16 \\
( \pm 0.04)\end{array}$ & $\begin{array}{l}52.16 \\
( \pm 0.06)\end{array}$ & $\begin{array}{l}58.65 \\
( \pm 0.11)\end{array}$ & $\begin{array}{l}6.55 \\
( \pm 0.02)\end{array}$ & $\begin{array}{l}4.10 \\
( \pm 0.06)\end{array}$ & $\begin{array}{l}14.97 \\
( \pm 0.03)\end{array}$ & $\begin{array}{l}28.53 \\
( \pm 0.06)\end{array}$ \\
\hline B2 & $9.49( \pm 0.13)$ & $\begin{array}{l}9.23 \\
( \pm 0.11)\end{array}$ & $\begin{array}{l}55.34 \\
( \pm 0.06)\end{array}$ & $\begin{array}{l}60.00 \\
( \pm 0.03)\end{array}$ & $\begin{array}{l}20.02 \\
( \pm 0.01)\end{array}$ & $\begin{array}{l}6.32 \\
( \pm 0.14)\end{array}$ & $\begin{array}{l}21.44 \\
( \pm 0.04)\end{array}$ & $\begin{array}{l}72.01 \\
( \pm 0.09)\end{array}$ \\
\hline B3 & $9.57( \pm 0.07)$ & $\begin{array}{l}13.12 \\
( \pm 0.24)\end{array}$ & $\begin{array}{l}53.44 \\
( \pm 0.06)\end{array}$ & $\begin{array}{l}59.15 \\
( \pm 0.19)\end{array}$ & $\begin{array}{l}20.35 \\
( \pm 0.02)\end{array}$ & $\begin{array}{l}5.65 \\
( \pm 0.18)\end{array}$ & $\begin{array}{l}11.51 \\
( \pm 0.02)\end{array}$ & $4.38( \pm 0.03)$ \\
\hline C1 & $9.36( \pm 0.02)$ & $\begin{array}{l}7.03 \\
( \pm 0.05)\end{array}$ & $\begin{array}{l}15.43 \\
( \pm 0.03)\end{array}$ & $\begin{array}{l}28.29 \\
( \pm 0.07)\end{array}$ & $\begin{array}{l}4.02 \\
( \pm 0.06)\end{array}$ & $\begin{array}{l}0.13 \\
( \pm 0.10)\end{array}$ & $\begin{array}{l}10.94 \\
( \pm 0.23)\end{array}$ & $4.74( \pm 0.17)$ \\
\hline C2 & $9.05( \pm 0.01)$ & $\begin{array}{l}5.93 \\
( \pm 0.09)\end{array}$ & $\begin{array}{l}13.34 \\
( \pm 0.03)\end{array}$ & $\begin{array}{l}25.20 \\
( \pm 0.45)\end{array}$ & $\begin{array}{l}5.03 \\
( \pm 0.03)\end{array}$ & $\begin{array}{l}0.13 \\
( \pm 0.03)\end{array}$ & $\begin{array}{l}12.07 \\
( \pm 0.22)\end{array}$ & $\begin{array}{l}23.08 \\
( \pm 0.01)\end{array}$ \\
\hline C3 & $9.35( \pm 0.09)$ & $7.71( \pm 0.12)$ & $\begin{array}{l}17.81 \\
( \pm 0.03)\end{array}$ & $\begin{array}{l}29.92 \\
( \pm 0.17)\end{array}$ & $\begin{array}{l}3.18 \\
( \pm 0.04)\end{array}$ & $\begin{array}{l}0.13 \\
( \pm 0.03)\end{array}$ & $\begin{array}{l}14.32 \\
( \pm 0.19)\end{array}$ & $\begin{array}{l}107.93 \\
( \pm 0.02)\end{array}$ \\
\hline D1 & $10.05( \pm 0.03)$ & $\begin{array}{l}23.03 \\
( \pm 0.03)\end{array}$ & $\begin{array}{l}70.14 \\
( \pm 0.07)\end{array}$ & $\begin{array}{l}66.47 \\
( \pm 0.08)\end{array}$ & $\begin{array}{l}5.37 \\
( \pm 0.09)\end{array}$ & $\begin{array}{l}0.31 \\
( \pm 0.05)\end{array}$ & $\begin{array}{l}15.02 \\
( \pm 0.05)\end{array}$ & $\begin{array}{l}28.22 \\
( \pm 0.02)\end{array}$ \\
\hline D2 & $9.12( \pm 0.02)$ & $\begin{array}{l}21.00 \\
( \pm 0.01)\end{array}$ & $\begin{array}{l}65.17 \\
( \pm 0.07)\end{array}$ & $\begin{array}{l}64.49 \\
( \pm 0.11)\end{array}$ & $\begin{array}{l}0.1 \\
( \pm 0.12)\end{array}$ & $\begin{array}{l}5.00 \\
( \pm 0.06)\end{array}$ & $\begin{array}{l}9.75 \\
( \pm 0.17)\end{array}$ & $\begin{array}{l}28.39 \\
( \pm 0.04)\end{array}$ \\
\hline D3 & $9.49( \pm 0.13)$ & $\begin{array}{l}25.03 \\
( \pm 0.17)\end{array}$ & $\begin{array}{l}71.12 \\
( \pm 0.07)\end{array}$ & $\begin{array}{l}68.45 \\
( \pm 0.23)\end{array}$ & $\begin{array}{l}6.38 \\
( \pm 0.18)\end{array}$ & $\begin{array}{l}0.17 \\
( \pm 0.01)\end{array}$ & $\begin{array}{l}13.48 \\
( \pm 0.03)\end{array}$ & $\begin{array}{l}14.60 \\
( \pm 0.11)\end{array}$ \\
\hline E1 & $9.79( \pm 0.12)$ & $\begin{array}{l}2.77 \\
( \pm 0.16)\end{array}$ & $\begin{array}{l}5.55 \\
( \pm 0.13)\end{array}$ & $\begin{array}{l}21.62 \\
( \pm 0.04)\end{array}$ & $\begin{array}{l}1.50 \\
( \pm 0.12)\end{array}$ & $\begin{array}{l}6.88 \\
( \pm 0.01)\end{array}$ & $\begin{array}{l}17.31 \\
( \pm 0.08)\end{array}$ & $5.09( \pm 0.16)$ \\
\hline E2 & $9.71( \pm 0.08)$ & $\begin{array}{l}2.13 \\
( \pm 0.06)\end{array}$ & $\begin{array}{l}5.02 \\
( \pm 0.02)\end{array}$ & $\begin{array}{l}20.01 \\
( \pm 0.05)\end{array}$ & $\begin{array}{l}0.82 \\
( \pm 0.02)\end{array}$ & $\begin{array}{l}3.95 \\
( \pm 0.03)\end{array}$ & $\begin{array}{l}16.07 \\
( \pm 0.04)\end{array}$ & $\begin{array}{l}54.90 \\
( \pm 0.09)\end{array}$ \\
\hline E3 & $9.38( \pm 0.10)$ & $\begin{array}{l}3.49 \\
( \pm 0.18)\end{array}$ & $\begin{array}{l}6.15 \\
( \pm 0.14)\end{array}$ & $\begin{array}{l}22.65 \\
( \pm 0.07)\end{array}$ & $\begin{array}{l}5.20 \\
( \pm 0.04)\end{array}$ & $\begin{array}{l}7.69 \\
( \pm 0.07)\end{array}$ & $\begin{array}{l}17.30 \\
( \pm 0.06)\end{array}$ & $9.48( \pm 0.09)$ \\
\hline
\end{tabular}

Nitrogen content and total organic matter were also considered (Table 2). There were significant differences in concentrations of $\mathrm{NH}_{4}{ }^{+}-\mathrm{N}$ and $\mathrm{NO}_{3}{ }^{-}-\mathrm{N}(\mathrm{P}<0.05, \mathrm{n}=3)$, in which the $\mathrm{NH}_{4}{ }^{+}-\mathrm{N}$ concentration in the samples of lake $A$ was obviously higher than that in other lakes, and the $\mathrm{NO}_{3}{ }^{-}-\mathrm{N}$ concentration in the samples of lake $\mathrm{B}$ was markedly higher. The total organic matter (TOM) of the three sampling points in the same lake was significantly different, but no obvious regularity was found. The $\mathrm{pH}$ of sediment samples was between 9.0-10.0. There was no significant difference in moisture content (MC) of sediment samples in the five lakes.

\section{Bacteria Diversity In Sediment Samples}


High-throughput sequencing sample description and alpha-diversity index of total bacteria (16S rRNA), SOB (soxB gene), and SRB ( $d s r$ B gene) in sediment samples were shown in Supplementary Table 1. The coverage of the sequencing libraries of all samples is over $96 \%$, most of which reached over $99 \%$, which could reflect the microbial community in each sample. Shannon index and Chao index were calculated. The results showed that the diversity of bacteria in most samples had little difference. However, there were some exceptions. The diversity of SOB in A1 and D3 samples and SRB in A3 sample was significantly lower than that in other samples. Table 3 summarized the correlation between diversity index and physicochemical characteristics of the samples. In all the samples, the a-diversity index of total bacteria, SOB and SRB was highly correlated with the salinity $\left(\mathrm{Na}^{+} / \mathrm{SO}_{4}{ }^{2-} / \mathrm{Cl}^{-}\right)$and concentration of $\mathrm{NO}_{3}{ }^{-}-\mathrm{N}$, while it had a low correlation with other parameters. Shannon and Chao indexs of total bacteria and SOB were negatively correlated with the salinity and concentration of $\mathrm{NO}_{3}{ }^{-}-\mathrm{N}$. The Shannon and Chao indexs of SRB were positively correlated with salinity, while were negatively correlated with $\mathrm{NO}_{3}{ }^{-} \mathrm{N}$ concentration. These results indicated that the diversity of total bacteria and $\mathrm{SOB}$ decreased with the increase of salinity, especially the total bacteria. With the increase of $\mathrm{NO}_{3}{ }^{-}{ }^{-} \mathrm{N}^{-}$concentration, the diversity of total bacteria, SOB and SRB all decreased.

Table 3

Correlation analysis between alpha-diversity and physicochemical parameters of soda lakes

\begin{tabular}{|lllllll|}
\hline Alpha-diversity & $\mathrm{Na}^{+} / \mathrm{SO}_{4}{ }^{2-} / \mathrm{Cl}^{-}$ & $\mathrm{NH}_{4}{ }^{+}-\mathrm{N}$ & $\mathrm{NO}_{3}{ }^{-}-\mathrm{N}$ & $\mathrm{TOM}$ & $\mathrm{pH}$ & $\mathrm{MC}$ \\
\hline 16s rRNA & & & & & & \\
\hline Shannon index & -0.491 & -0.269 & $-0.636^{*}$ & 0.011 & -0.09 & -0.139 \\
\hline Chao index & $-0.633^{*}$ & 0.007 & -0.568 & 0.29 & -0.306 & -0.057 \\
\hline SOB & & & & & & \\
\hline Shannon index & -0.316 & -0.280 & -0.361 & -0.032 & -0.088 & -0.286 \\
\hline Chao index & -0.196 & -0.358 & -0.561 & 0.032 & 0.241 & -0.343 \\
\hline SRB & & & & & & \\
\hline Shannon index & 0.302 & -0.364 & $-0.650^{*}$ & 0.056 & 0.462 & -0.203 \\
\hline Chao index & 0.151 & -0.203 & $-0.727^{*}$ & 0.091 & 0.256 & -0.154 \\
\hline Note: ${ }^{*}$ represents significant correlation, ${ }^{*} \mathrm{P}<0.05$ & & & \\
\hline
\end{tabular}

\section{Total Bacterial Community In Sediment Samples}

We compared and annotated sequencing results of 16s rRNA and performed taxonomic analysis on phylum level (Fig. 2A). Total bacterial community mainly included phyla Proteobacteria (11.34-46.00\%), Bacteroidetes (10.10-45.24\%), Halanaerobiaeota (0.03-53.53\%), Firmicutes (0.73-21.95\%), Actinobacteria (0.75-16.31\%) and Gemmatimonadetes (0.1$17.59 \%)$. The results showed that there were quite differences in bacterial composition among the samples from different lakes. However, three samples from the same lake, with similar physicochemical parameters, had similar bacterial composition, which indicated that the physicochemical parameters were important factors affecting the bacterial composition. Meanwhile, it should be noted that the bacterial diversity of samples B and D with high salinity was lower than that of other samples, and the content of phyla Haloanaerobiaeota, which was famous for its salt tolerance and anaerobic characteristics, was significantly higher than that of other samples. 


\section{Sob Community In Sediment Samples}

Many microorganisms, including obligate anaerobes, facultative anaerobes and aerobic bacteria, play roles in sulfur oxidation (Ghosh and Dam, 2009; Jung et al. 2010). Based on the results of high-throughput sequencing of soxB gene, the taxonomic composition of SOB was analyzed on genus level (Fig. 2B, Supplementary Fig. 1A), in which 26 SOB genera were detected, including Thioalkalivibrio (Gammaproteobacteria), Burkholderia and Hydrogenophaga (Betaproteobacteria), Paracoccus, Bradyrhizobium (Alphaproteobacteria) and so on. The compositions of SOB were different in the sediment samples of five soda lakes. However, the cluster of bacteria was basically consistent with the sampling sites, that was, the samples from the same lake had similar composition and proportion of SOB. On the whole, based on the annotated results, the diversity of SOB was relatively low. Thioalkalivibrio was found dominant in the majority of samples with relative abundances ranging from $0.9-81.7 \%$. Burkholderia was only detected in the sediment samples of lakes $A$ and $E$ with a low salinity, and the relative abundance was the highest in the sediment samples of lake E3, which was as high as $10.3 \%$. Paracoccus was found in a small amount of the majority of samples, while it was relatively high in lakes $A$ and $E$ with a low salinity, which reached $5.92 \%$, and the abundance of Hydrogenophaga was $4.51 \%$ only in lake C. Purple non-sulfur bacteria and purple sulfur bacteria, including Rhodoplanes (0.94\%) and Halorhodospira $(0.58 \%)$, were detected in lake D with a high salinity.

\section{Srb Community In Sediment Samples}

Based on the results of high-throughput sequencing of $d s r B$ gene, the taxonomic composition of SRB was analyzed at the genus level (Fig. 2C, Supplementary Fig. 1B), and it was revealed that 39 SRB genera, including Desulfurivibrio, Candidatus Electrothrix, Desulfonatronum, Desulfonatronovibrio, Desulfonatronobacter, Desulfohalophilus,

Desulfonatronospira and so on, all belong to the deltaproteobacteria class. It was observed that the community structure of the SRB varied across the different soda lakes. Similar to SOB, the cluster of SRB was consistent with the sampling sites. However, compared with SOB, the diversity of SRB was higher in all samples. Desulfunvibno was detected in the majority of the samples, while it was dominant only in lake $D$ with a high-salinity, and the relative abundance was as high as $28.09 \%$. The relative abundances of Candidatus Electrothrix, Desulfonatronum, and Desulfonatronovibrio were relatively high in lakes $A$ and $E$ with a low-salinity, and the highest abundance was $38.58 \%, 43.20 \%$, and $17.45 \%$, respectively. Desulfonatronospira and Desulfohalophilus were found to have higher abundance only in lakes B and D with a high salinity, which reached $18.69 \%$ and $8.79 \%$, respectively. Desulfonatronobacter was detected to have a higher abundance in lake $B$, which was as high as $22.70 \%$.

\section{Effects of physicochemical factors on the SOB and SRB community}

To illustrate the relationship between the microbial communities and physicochemical characteristics in soda lakes, Spearman's correlation analysis and Redundant analysis (RDA) were conducted. Spearman correlation analysis showed that most of the dominant $\mathrm{SOB}$ were highly correlated with the concentrations of $\mathrm{NH}_{4}{ }^{+}-\mathrm{N}$ and salinity $\left(\mathrm{Na}^{+}\right)(\mathrm{Table} 4)$. Specifically, Bradyrhizobium, stappia and rhodoplanes were positively correlated with salinity. Burkholderia and Paracoccus were positively correlated with $\mathrm{NH}_{4}{ }^{+}-\mathrm{N}$ concentration, while Bradyrhizobium and Hydrogenophaga were the opposite. In addition, Bradyrhizobium and Hydrogenophaga were significantly affected by MC. As the main SOB in the soda lake, Thioalkalivibrio was not significantly affected by the factors investigated, which indicated that Thioalkalivibrio had a wide range of adaptability. Overall, as shown in Fig. $3 \mathrm{~A}, \mathrm{NH}_{4}{ }^{+}-\mathrm{N}$ was the most important factor influencing the composition of SOB in the soda lake, followed by salinity. 
Table 4

Correlation analysis between SOB, SRB and physicochemical parameters of soda lakes

\begin{tabular}{|c|c|c|c|c|c|c|}
\hline Bacteria & $\mathrm{Na}^{+} / \mathrm{SO}_{4}{ }^{2-} / \mathrm{Cl}^{-}$ & $\mathrm{NH}_{4}^{+}-\mathrm{N}$ & $\mathrm{NO}_{3}{ }^{-}-\mathrm{N}$ & TOM & $\mathrm{pH}$ & MC \\
\hline \multicolumn{7}{|l|}{ SOB } \\
\hline Thioalkalivibrio & 0.164 & 0.409 & 0.196 & 0.268 & -0.111 & 0.261 \\
\hline Burkholderia & -0.497 & $0.608^{*}$ & -0.436 & -0.364 & -0.192 & 0.234 \\
\hline Paracoccus & -0.065 & $0.552^{*}$ & 0.062 & -0.153 & 0.044 & 0.366 \\
\hline Bradyrhizobium & $0.611^{*}$ & $-0.574^{*}$ & -0.130 & -0.077 & 0.082 & $-0.576^{*}$ \\
\hline Hydrogenophaga & 0.364 & $-0.566^{*}$ & -0.165 & -0.133 & -0.023 & $-0.545^{\star}$ \\
\hline Stappia & $0.560^{\star}$ & -0.189 & -0.005 & 0.335 & 0.046 & -0.183 \\
\hline Halorhodospira & 0.484 & -0.179 & $0.516^{*}$ & -0.161 & -0.014 & -0.296 \\
\hline Rhodoplanes & $0.553^{*}$ & -0.145 & -0.199 & 0.133 & 0.211 & -0.248 \\
\hline \multicolumn{7}{|l|}{ SRB } \\
\hline Desulfurivibrio & 0.367 & -0.524 & -0.091 & 0.448 & 0.312 & -0.259 \\
\hline Candidatus Electrothrix & $-0.674^{*}$ & $0.711^{*}$ & -0.458 & -0.366 & -0.095 & 0.394 \\
\hline Desulfonatronospira & $0.583^{*}$ & -0.399 & $0.657^{\star}$ & 0.084 & -0.291 & -0.343 \\
\hline Desulfonatronum & $-0.725^{\star \star}$ & 0.495 & $-0.605^{\star}$ & -0.011 & 0.152 & 0.470 \\
\hline Desulfonatronovibrio & -0.429 & 0.502 & -0.573 & -0.011 & 0.027 & 0.431 \\
\hline Desulfonatronobacter & -0.194 & 0.245 & 0.490 & 0.028 & -0.091 & 0.273 \\
\hline Desulfohalophilus & $0.758^{\star \star}$ & $-0.741^{\star \star}$ & 0.046 & 0.183 & 0.294 & -0.528 \\
\hline
\end{tabular}

As shown in Table 4 and Fig. 3B, the influence of physicochemical factors on SRB composition was analyzed. Similar to $\mathrm{SOB}$, salinity and $\mathrm{NH}_{4}{ }^{+}-\mathrm{N}$ had significant effects on SRB. Candidatus electrothrix and Desulfonatronum were negatively correlated with salinity, while Desulfonatronospira and Desulfonalophilus were on the contrary. For the effect of $\mathrm{NH}_{4}{ }^{+}-\mathrm{N}$, it was found that the significant effect of $\mathrm{NH}_{4}{ }^{+}-\mathrm{N}$ on Candidatus electrotherix was positively correlated, while the effect on Desulfohalophilus was negatively correlated. Different with $\mathrm{SOB}$ analysis, the effect of $\mathrm{NO}_{3}{ }^{-}{ }^{-} \mathrm{N}$ concentration on SRB was more obvious, especially on Desulfonatronospira and Desulfonatronum. Desulfurivibrio was the main SRB bacteria in soda lakes, which had strong adaptability and was not affected by environmental factors, which was similar to Thioalkalivibrio. In short, salinity was noted as the most important factor that influenced the composition of SRB, followed by the $\mathrm{NO}_{3}{ }^{-}-\mathrm{N}$ and $\mathrm{NH}_{4}{ }^{+}-\mathrm{N}$. In addition, it can be seen from the above data that $\mathrm{TOM}, \mathrm{pH}$ and $\mathrm{MC}$ had no significant effect on the composition of SOB and SRB.

\section{Co-occurences Of Sob And Srb}


In order to study the interaction between SOB and SRB, we used R programming language and Gephi 0.9.2 software to analyze and draw a network diagram. As shown in Fig. 4, there were 65 nodes (bacteria) and 309 edges in the graph. A group of closely associated microorganisms in the microbial network were divided into the same module. The bacterium in the same module had similar niches. The colors of different nodes denoted different modules. As shown in Fig. 4, there were 5 modules $(\mathbb{Z}-\mathbb{Z})$, and the proportion of each module was $29.23 \%, 18.46 \%, 18.46 \%, 15.38 \%$ and $6.15 \%$. The network diagram showed the complex relationship between sulfur metabolizing bacteria in soda lake sediments. Most SRB were distributed in the same module (module $\Downarrow$ ), which indicated that their functions were similar and had relatively close niche. Similar to SRB, photophilic sulfur oxidizing bacteria were mostly found in module III. However, as the highest abundance of SOB, Thioalkalivibrio occupied a less important position, which implied the diversity of sulfur oxidizers and their unimportance in determining the niche.

It can be seen that Rhodoplanes was highly connected with other bacteria, which was called kinless hubs, although its relative abundance was low in the samples. Previous research had shown that the relative abundance of taxa classified as kinless hubs within the ecological network were positively and significantly correlated with the abundance of functional genes (Shi et al. 2020). The demise of kinless hubs would bring huge changes to the community structure and its functions (Banerjee et al. 2018). Rhodoplanes had a unique position in the microbial community of this study. Rhodoplanes was a kind of purple non-sulfur bacteria, which belonged to Alphaproteobacteria (Okamura et al. 2009). Rhodoplanes could grow aerobically in the atmosphere or grow anaerobically through denitrification in the dark, but the preferred growth way was to use simple organic acids, such as pyruvate, for anaerobic organic growth (Chakravarthy et al. 2012). Rhodoplanes had been reported to have an optimal pH of 7.0 (Chakravarthy et al. 2012). However, it was found that Rhodoplanes play an important role in the community of soda lake sediments, indicating the existence of some haloalkalophilic Rhodoplanes species.

\section{Discussion}

\section{Diversity of the sulfur bacteria community in soda lakes}

For the first time, we depended high-throughput sequencing of 16S rRNA, soxB and dsrB genes to accurately estimate phylogenetic richness and composition in five soda lakes with different physicochemical factors, located in Ordos, Inner Mongolia Autonomous Region, China. A surprisingly diverse bacterial community was discovered in five lake sediments. The bacterial community was dominated by the phyla Proteobacteria, Bacteroidetes, Halanaerobiaeota, Firmicutes, Actinobacteria and Gemmatimonadetes. From the results, it was found that chemolithoautotrophic genus Thioalkalivibrio covered the whole spectrum of salinity, $\mathrm{NO}_{3}{ }^{-}, \mathrm{NH}_{4}{ }^{+}$conditions present in soda lakes. Thioalkalivibrio presented the obvious physiological diversity, the most prominent of which was that, the dominant subgroup of this genus was able to grow in saturated soda brines containing $4 \mathrm{M}$ total $\mathrm{Na}^{+}$(Sorokin et al. 2011). Due to its strong contribution in biological desulfurization process, the growth characteristics of Thioalkalivibrio have been studied in depth (Mu et al. 2016; Grant and Sorokin, 2011), and the genome editing methods for Thioalkalivibrio have been established (Sharshar et al. 2020). Important genes related to sulfur oxidation, such as fcc, sox, and sat/apr, have been detected in most of Thioalkalivibrio genus that have been sequenced, indicating that the genus has rich sulfur oxidation pathways, making it can adapt to more complex environments, and contribute to the sulfur cycling process, which was consistent with the results of the present study (Foti et al. 2006; Liu et al. 2021).

Although our data highlighted the importance of Thioalkalivibrio to sulfur biogeochemistry in soda lakes, purple nonsulfur bacteria and purple sulfur bacteria, including Rhodoplanes (0.94\%) and Halorhodospira (0.58\%), were detected in lake D with a high salinity. Photoheterotrophic bacteria could oxidize sulfide, thiosulfate and sulfur to sulfate during heterotrophic growth with additional energy benefit and occupy the niche rapidly, which made them in a favorable 
position in the rapidly changing environment of soda lakes (Tourova et al. 2013). In addition, heterotrophic sulfur oxidizing bacteria Halomonas was also detected by soxB gene. The most remarkable feature of the bacteria was their ability to grow and concomitantly oxidize sulfide and polysulfide to elemental sulfur anaerobically under denitrifying conditions (Sorokin and Kuenen, 2005).

The reductive part of the sulfur cycle was active in the anoxic layers of the sediments of soda lakes. Microbiological analysis indicated a domination of haloalkaliphilic SRB, including Desulfurivibrio, Candidatus Electrothrix,

Desulfonatronovibrio, Desulfonatronum and Desulfonatronospira. At present, 15 genera of haloalkaliphilic SRB had been isolated, of which 11 strains have completed genome sequencing. Most of these bacteria were isolated from soda lakes in Russia, the United States and Kenya (Sorokin et al. 2015). Desulfurivibrio had the characteristics of elemental sulfur disproportionation to adapt to the environment and became the dominant bacteria (Poser et al. 2013). Recent studies suggested that Desulfurivibrio might have the potential of extracellular electron transfer, because similar conductive pili synthesis genes responsible for electron transfer had been detected in the genome of D. alkaliphiles (Melton et al. 2016; $\mathrm{Ni}$ et al. 2019). Although whether Desulfurivibrio could carry out extracellular electron transfer still needed further verification, it was speculated that Desulfurivibrio played an important role in the electron sharing of anaerobic bacterial community.

In addition, a great number of Candidatus Electrothrix were firstly detected in the sediment samples of soda lakes with a low salinity. Candidatus Electrothrix was a kind of filamentous multicellular microorganism, which can electrically couple the oxygen reduction on the surface of the sediment with the oxidation of sulfide in the deep hypoxic layer through long-distance electron transmission (Trojan et al. 2016). Candidatus Electrothrix can also use nitrate or nitrite as an electron acceptor to couple nitrate reduction and sulfide oxidation to transfer electrons over a long distance (Bjerg et al. 2018). Uniquely, it can perform sulfide oxidation and sulfate reduction at the same time (Nielsen et al. 2010), but in this study, Candidatus Electrothrix was not detected with soxB as the marker gene. It should be because most strains of this genus use opposite pathway of classical sulfur reduction to complete sulfur oxidation. (Müller et al. 2020).

\section{Salinity, $\mathrm{NH}_{4}{ }^{+}-\mathrm{N}$ and $\mathrm{NO}_{3}{ }^{-} \mathrm{N}$ were the significant factors}

We compared the effects of salinity, nitrogen and other physicochemical parameters on the diversity and composition of total bacteria, SOB and SRB. In general, salinity, $\mathrm{NH}_{4}{ }^{+}$and $\mathrm{NO}_{3}{ }^{-}$concentration were the most important factors. The diversity of total bacteria and SOB was negatively correlated with salinity. It has been proved that salinity can cause changes in the sulfur cycle. There were two sulfur cycles in soda lakes mainly depending on the salinity of the lake water. At medium salinity, a complete sulfur cycle, namely "long" sulfur cycle, is more likely between $\mathrm{HS}^{-}$and $\mathrm{SO}_{4}{ }^{2-}$, where $\mathrm{HS}^{-}$is completely oxidized to $\mathrm{SO}_{4}{ }^{2-}$, and $\mathrm{SO}_{4}{ }^{2-}$ is reduced to $\mathrm{HS}^{-}$by SRB. Under saturation salinity, the cycle may be shortened due to the presence of sulfur intermediate products such as $\mathrm{S}^{0}, \mathrm{Sn}^{2-}, \mathrm{S}_{2} \mathrm{O}_{3}{ }^{2-}$, namely "short" sulfur cycle. In this cycle, $\mathrm{HS}^{-}$is not completely oxidized to $\mathrm{S}_{2} \mathrm{O}_{3}{ }^{2-}$, and then formed $\mathrm{HS}^{-}$by sulfur reduction reaction (Sorokin et al. 2011).

Additionally, it was showed that the diversity of total bacteria and SRB was significantly correlated with $\mathrm{NO}_{3}{ }^{-}$, and the RDA analysis revealed that $\mathrm{NO}_{3}{ }^{-}$was the second important factor influencing the composition of SRB. This could be related to the high $\mathrm{NO}_{3}{ }^{-}$concentration contributing to the growth of denitrifying bacteria (DNB), because the intermediate products of denitrifying, e.g. $\mathrm{NO}$ and $\mathrm{N}_{2} \mathrm{O}$, could inhibit the growth of SRB (Zumft, 1993). Moreover, studies demonstrated that DNB could preferentially use matrix, thus, it possessed an advantage compared with SRB (Chidthaisong and Conrad, 2000). In addition, $\mathrm{NO}_{3}{ }^{-}$is an important electron acceptor for $\mathrm{SOB}$, especially in oxygen 
deficient environment. Now, three out of nine Thioalkalivibrio species had been confirmed to be able to grow anaerobically with $\mathrm{NO}_{3}{ }^{-}$as electron acceptor.

\section{Rhodoplanes was the core bacterium}

In the process of sulfur cycle in soda lakes, there were complex relationships between sulfur related bacteria. Many species of bacteria were located in the same niche, which indicated the complexity of sulfur cycle in soda lakes and the redundancy of the same functional bacteria, which ensured the stability of the system to the maximum extent. According to the co-occurences of SOB and SRB, it was found that the bacteria with high abundance was not the kinless hubs. The most representative example was Thioalkalivibrio, which had little contact with other bacteria. The results showed that Rhodoplanes was the core bacterium, which may be related to its metabolic diversity. This genus comprised purple non-sulfur bacteria expressing preferably photoheterotrophic growth in the light under anoxic conditions, whereas chemoorganotrophic growth was possible in the dark under both oxic and anoxic conditions. Due to its metabolic versatility, Rhodoplanes has been isolated from very diverse aquatic environments, ranging from freshwater through to activated sludge in wastewater treatment plants (Rojas et al. 2018).

\section{Conclusions}

In this paper, the high-throughput sequencing of $16 \mathrm{~s} r \mathrm{RNA}, d s r \mathrm{~B}$, and soxB genes was carried out, and the microbial communities in different soda lakes were analyzed. The results showed that most of the total bacteria in soda lakes belong to phyla Proteobacteria, Bacteroidetes, Halanaerobiaeota, Firmicutes, and Actinobacteria. SOB and SRB were broadly distributed in soda lakes. The detected SOB was affiliated to Alpha-, Beta- and Gamma-proteobacteria populations, while most of SRB was affiliated to Deltaproteobacteria. The distribution of SOB and SRB was significantly affected by levels of salinity and inorganic nitrogen. The communities of SOB, mainly including Thioalkalivibrio, Burkholderia, Paracoccus, Bradyrhizobium, and Hydrogenophaga genera, were remarkably influenced by the levels of $\mathrm{NH}_{4}{ }^{+} \mathrm{N}$ and salinity. For SRB communities, including Desulfurivibrio, Candidatus Electrothrix, Desulfonatronospira, Desulfonatronum, Desulfonatronovibrio, Desulfonatronobacter and so on, the most significant determinants were salinity and $\mathrm{NO}_{3}{ }^{-}-\mathrm{N}$. Besides, Rhodoplanes played a significant role in the interaction between SOB and SRB. In summary, this study extended our knowledge regarding the distribution of community structures of SOB and SRB under haloalkaline conditions.

\section{Declarations}

Acknowledgments This article acknowledges the funding support provided by the National Key Research \& Development Program of China (No. 2020YFA0906800) and National Science Foundation of China (Nos. 31872633, 21878307 and 31800030).

Author contributions $\mathrm{MH} Y$ and JM X designed the experiment and wrote the first draft. XY L, TZ M, DL M, and JL L collected the fecal samples and performed preliminary preparation. All authors have helped in revision and approved the final manuscript.

Declaration of Competing Interest The authors declare that they have no known competing financial interests or personal relationships that could have appeared to influence the work reported in this paper.

\section{References}


1. Asnicar F, Weingart G, Tickle TL, Huttenhower C, Segata N (2015) Compact graphical representation of phylogenetic data and metadata with GraPhIAn. PeerJ 3:e1029

2. Banerjee S, Schlaeppi K, van der Heijden MG (2018) Keystone taxa as drivers of microbiome structure and functioning. Nat Rev Microbiol 16(9):567-576

3. Bastian M, Heymann S, Jacomy M (2009) Gephi: an open source software for exploring and manipulating networks. Icwsm 8:361-362

4. Berben T, Overmars L, Sorokin DY, Muyzer G (2019) Diversity and distribution of sulfur oxidation-related genes in Thioalkalivibrio, a genus of chemolithoautotrophic and haloalkaliphilic sulfur-oxidizing bacteria. Front Microbio. doi: 10.3389/fmicb.2019.00160

5. Bjerg JT, Boschker HT, Larsen S, Berry D, Schmid M, Millo D, Tataru P, Meysman FJR, Wagner M, Nielsen LP, Schramm A (2018) Long-distance electron transport in individual, living cable bacteria. Proc Natl Acad Sci 115(22):5786-5791

6. Bokulich NA, Kaehler BD, Ram RJ, Matthew D, Evan B, Rob K, Huttley GA, Gregory CJ (2018) Optimizing taxonomic classification of marker-gene amplicon sequences with qiime 2's q2-feature-classifier plugin. Microbiome 6(1):90

7. Chakravarthy SK, Ramaprasad EVV, Shobha E, Sasikala C, Ramana CV (2012) Rhodoplanes piscinae sp. nov. isolated from pond water. Int J Syst Evol Microbiol 62(12):2828-2834

8. Chidthaisong A, Conrad R (2000) Turnover of glucose and acetate coupled to reduction of nitrate, ferric iron and sulfate and to methanogenesis in anoxic rice field soil. FEMS Microbiol Ecol 31(1):73-86

9. Edwardson CF, Hollibaugh JT (2018) Composition and activity of microbial communities along the redox gradient of an alkaline, hypersaline, lake. Front Microbiol. doi: 10.3389/fmicb.2018.00014

10. Foti M, Ma S, Sorokin DY, Rademaker JLW, Kuenen JG, Muyzer G (2006) Genetic diversity and biogeography of haloalkaliphilic sulphur-oxidizing bacteria belonging to the genus Thioalkalivibrio. FEMS Microbiol Ecol 56(1):95101

11. Furian S, Martins ERC, Parizotto TM, Rezende-Filho AT, Victoria RL, Barbiero L (2013) Chemical diversity and spatial variability in myriad lakes in Nhecolandia in the Pantanal wetlands of Brazil. Limnol Oceanogr 58(6):2249-2261

12. Gao P, Tian H, Li G, Sun HW, Ma T (2015) Microbial diversity and abundance in the Xinjiang Luliang long-term waterflooding petroleum reservoir. Microbiologyopen 4(2):332-342

13. Ghosh W, Dam B (2009) Biochemistry and molecular biology of lithotrophic sulfur oxidation by taxonomically and ecologically diverse bacteria and archaea. FEMS Microbiol Rev 33(6):999-1043

14. Giloteaux L, Duran R, Casiot C, Bruneel O, Elbaz-Poulichet F, Goñi-Urriza M (2013) Three-year survey of sulfatereducing bacteria community structure in Carnoules acid mine drainage (France), highly contaminated by arsenic. FEMS Microbiol Ecol 83(3):724-737

15. Gorlenko VM (2007) Anoxygenic phototrophic bacteria from soda lakes.Trans Winogradsky Inst Microbiol. XIV:159183

16. Grant WD, Sorokin DY (2011) Distribution and Diversity of Soda Lake Alkaliphiles. Extremophiles handbook. 1: 2754

17. Ihaka R, Gentleman R (1996) R: a language for data analysis and graphics. J Comput Graph Stat 5(3):299-314

18. Jung MY, Pham VH, Park SJ, Kim SJ, Chae JC, Roh Y, Rhee SK (2010) Metagenomic assessment of a sulfuroxidizing enrichment culture derived from marine sediment. J Microbiol 48(6):739-747

19. Katoh K, Misawa K, Kuma KI, Miyata T (2002) Mafft: a novel method for rapid multiple sequence alignment based on fast fourier transform. Nucleic Acids Res 30(14):3059-3066 
20. Koljalg U, Nilsson RH, Abarenkov K, Tedersoo L, Taylor AFS, Bahram M, Bates ST, Bruns TD, Bengtsson-Palme J, Callaghan TM, Douglas B, Drenkhan T, Eberhardt U, Dueñas M, Grebenc T, Griffith GW, Hartmann M, Kirk PM, Kohout P, Larsson E, Lindahl BD, Lücking R, Martín MP, Matheny PB, Nguyen NH, Niskanen T, Oja J, Peay KG, Peintner U, Peterson M, Põldmaa K, Saag L, Saar I, Schüßler A, Scott JA, Senés C, Smith ME, Suija A, Taylor DL, Telleria MT, Weiss M, Larsson KH (2013) Towards a unified paradigm for sequence-based identification of fungi. Mol Ecol 22(21):5271-5277

21. Liu ZX, Yang MH, Mu TZ, Liu JL, Xing JM (2021) Transcriptional response of Thialkalivibrio versutus D301 to different sulfur sources and identification of the sulfur oxidation pathways. J Biotechnol 329:160-169

22. Martin M (2011) Cut adapt removes adapter sequences from high-throughput sequencing reads. EMB net 17(1):1012

23. Melton ED, Sorokin DY, Overmars L, Chertkov O, Clum A, Pillay M, Ivanova N, Shapiro N, Kyrpides NC, Woyke T (2016) Complete genome sequence of Desulfurivibrio alkaliphilus strain AHT2T, a haloalkaliphilic sulfidogen from Egyptian hypersaline alkaline lakes. Stand Genomic Sci 11:67

24. Meyer B, Imhoff JF, Kuever J (2007) Molecular analysis of the distribution and phylogeny of the soxB gene among sulfur-oxidizing bacteria-evolution of the Sox sulfur oxidation enzyme system. Environ Microbiol 9(12):2957-2977

25. Mu TZ, Zhou JM, Yang MH, Xing JM (2016) Complete genome sequence of Thialkalivibrio versutus D301 isolated from Soda Lake in northern China, a typical strain with great ability to oxidize sulfide. J Biotechnol 227:21-22

26. Müller H, Marozava S, Probs AJ, Meckenstock RU (2020) Groundwater cable bacteria conserve energy by sulfur disproportionation. ISME J 14(2):623-634

27. Ni GF, Harnawan P, Seidel L, Heijne AT, Sleutels T, Buisman CJN, Dopson M (2019) Haloalkaliphilic microorganisms assist sulfide removal in a microbial electrolysis cell. J Hazard Mater 363:197-204

28. Nielsen LP, Risgaard-Petersen N, Fossing H, Christensen PB, Sayama M (2010) Electric currents couple spatially separated biogeochemical processes in marine sediment. Nature 463(7284):1071-1074

29. Okamura K, Kanbe T, Hiraishi A (2009) Rhodoplanes serenus sp. nov., a purple non-sulfur bacterium isolated from pond water. Int J Syst Evol Microbiol 59(3):531-535

30. Poser A, Lohmayer R, Vogt C, Knoeller K, Kai F (2013) Disproportionation of elemental sulfur by haloalkaliphilic bacteria from soda lakes. Extremophiles 17:1003-1012

31. Price MN, Dehal PS, Arkin AP (2009) FastTree: computing large minimum evolution trees with profiles instead of a distance matrix. Mol Biol Evol 26(7):1641-1650

32. Rastogi G, Stetler LD, Peyton BM, Sani RK (2009) Molecular analysis of prokaryotic diversity in the deep subsurface of the former Homestake gold mine, South Dakota, USA. J Microbiol 47(4):371-384

33. Rojas P, Rodríguez N, Fuente V, Sánchez-Mata D, Amils R, Sanz JL (2018) Microbial diversity associated with the anaerobic sediments of a soda lake (Mono Lake, California, USA). Can J Microbiol 64:385-392

34. Santisteban JI, Mediavilla R, López-Pamo E, Dabrio CJ, Blanca Ruiz Zapata M, José Gil García M, Castaño S, Martínez-Alfaro PE (2004) Loss on ignition: a qualitative or quantitative method for organic matter and carbonate mineral content in sediments? J Paleolimnol 32(3):287-299

35. Schagerl M, Renaut RW (2016) "Dipping into the soda lakes of East Africa. " Soda Lakes of East Africa. Springer, pp 3-24

36. Sharshar MM, Samak NA, Ambreen S, Hao XM, Mu TZ, Maarouf M, Zheng C, Gao YB, Liu ZX, Jia YP, Li XY, Zhong W, Peh S, Yang MH, Xing JM (2020) Improving confirmed nanometric sulfur bioproduction using engineered Thioalkalivibrio versutus. Bioresour Technol 317:124018

37. Sheibley RW, Duff JH, Jackman AP, Triska FJ (2003) Inorganic nitrogen transformations in the bed of the Shingobee River, Minnesota: Integrating hydrologic and biological processes using sediment perfusion cores. Limnol Oceanogr

Page 14/19 
48(3):1129-1140

38. Shi Y, Delgado-Baquerizo M, Li Y, Yang YF, Zhu YG, Peñuelas J, Chu HY (2020) Abundance of kinless hubs within soil microbial networks are associated with high functional potential in agricultural ecosystems. Environ Int 142:105869

39. Sorokin DY (2017) Anaerobic haloalkaliphiles. Encyclopedia Life Sciences 1-16

40. Sorokin DY, Banciu HL, Muyzer G (2015) Functional microbiology of soda lakes. Curr Opin Microbiol 25:88-96

41. Sorokin DY, Detkova EN, Muyzer G (2011) Sulfur-dependent respiration under extremely haloalkaline conditions in soda lake 'acetogens' and the description of Natroniella sulfidigena sp. nov. FEMS Microbiol Lett 319:88-95

42. Sorokin DY, Kuenen JG (2005) Haloalkaliphilic sulfur-oxidizing bacteria in soda lakes. FEMS Microbiol Rev 29:685702

43. Sorokin DY, Kuenen JG, Muyzer G (2011) The Microbial Sulfur Cycle at Extremely Haloalkaline Conditions of Soda Lakes. Front Microbiol 2:44

44. Tian H, Gao P, Chen Z, Li Y, Li Y, Wang Y, Zhou J, Li G, Ma T (2017) Compositions and abundances of sulfatereducing and sulfur-oxidizing microorganisms in water-flooded petroleum reservoirs with different temperatures in China. Front Microbiol 8:143

45. Tourova TP, Slobodova NV, Bumazhkin BK, Kolganova TV, Muyzer G, Sorokin DY (2013) Analysis of community composition of sulfur-oxidizing bacteria in hypersaline and soda lakes using soxB as a functional molecular marker. FEMS Microbiol Ecol 84(2):280-289

46. Trojan D, Schreiber L, Bjerg JT, Bøggild A, Yang TT, Kjeldsen KU, Schramm A (2016) A taxonomic framework for cable bacteria and proposal of the candidate genera Electrothrix and Electronema. Syst Appl Microbiol 39:297-306

47. White JR, Nagarajan N, Pop M (2009) Statistical methods for detecting differentially abundant features in clinical metagenomic samples. PLoS Comput Biol 5(4):e1000352

48. Xu DY, Kang XW, Zhuang DF, Pan JJ (2010) Multi-scale quantitative assessment of the relative roles of climate change and human activities in desertification-A case study of the Ordos Plateau, China. J Arid Environ 74(4):498507

49. Zhang Y, Wang X, Zhen Y, Mi T, He H, Yu Z (2017) Microbial diversity and community structure of sulfate-reducing and sulfur-oxidizing bacteria in sediment cores from the east China sea. Front Microbiol 8:2133

50. Zumft WG (1993) The biological role of nitric oxide in bacteria. Arch Microbiol 160(4):253-264

\section{Figures}




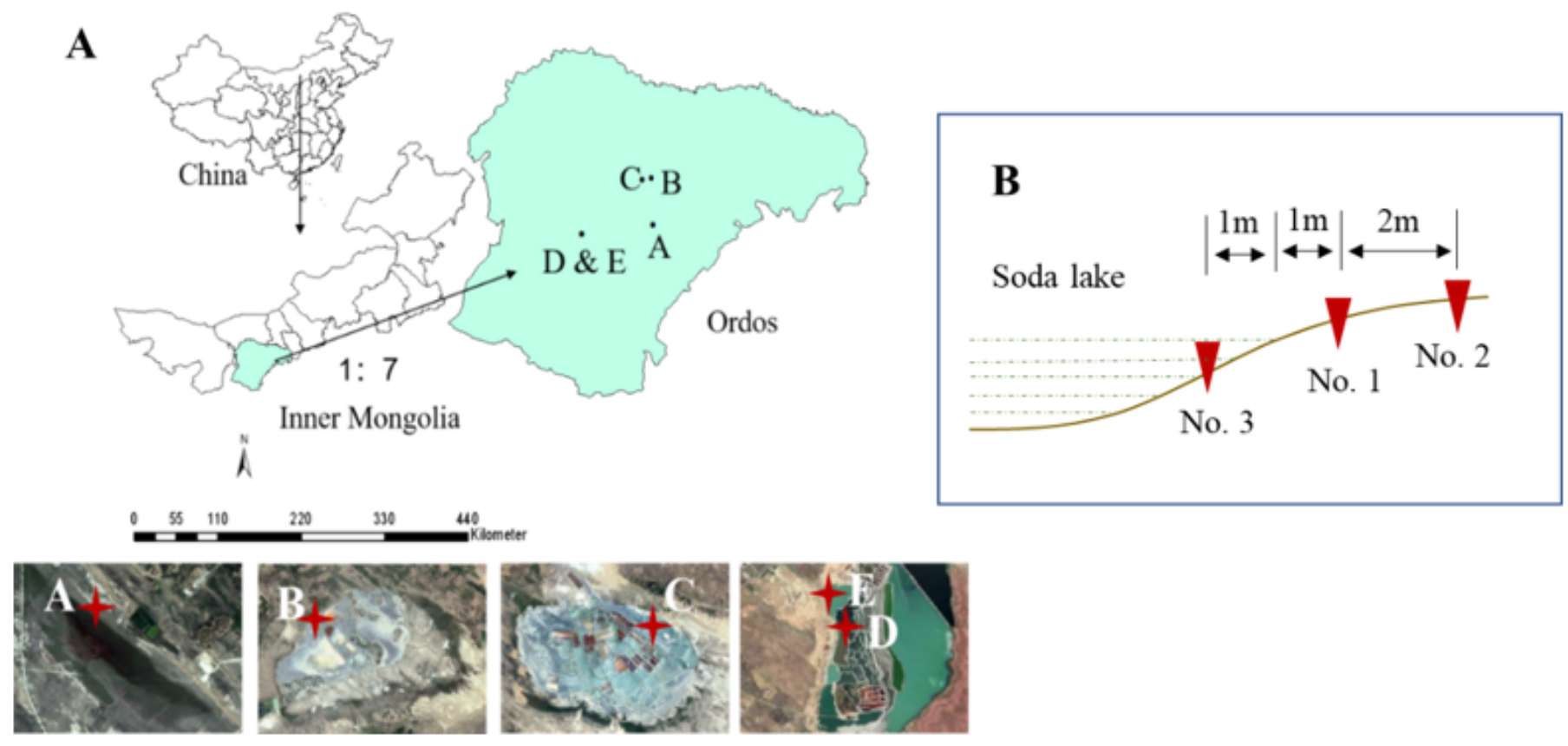

Figure 1

$<p>$ (A) Locations of the soda lakes. A, Haole Baoji Nao; B, Xiaohu; C, Bayin Naoer; D, Hama Rige Tainao Er, Salt Pond No. 1; E, Hama Rige Tainao Er, Salt Pond No. 2; (B) Locations of three sampling points for each lake.</p> 

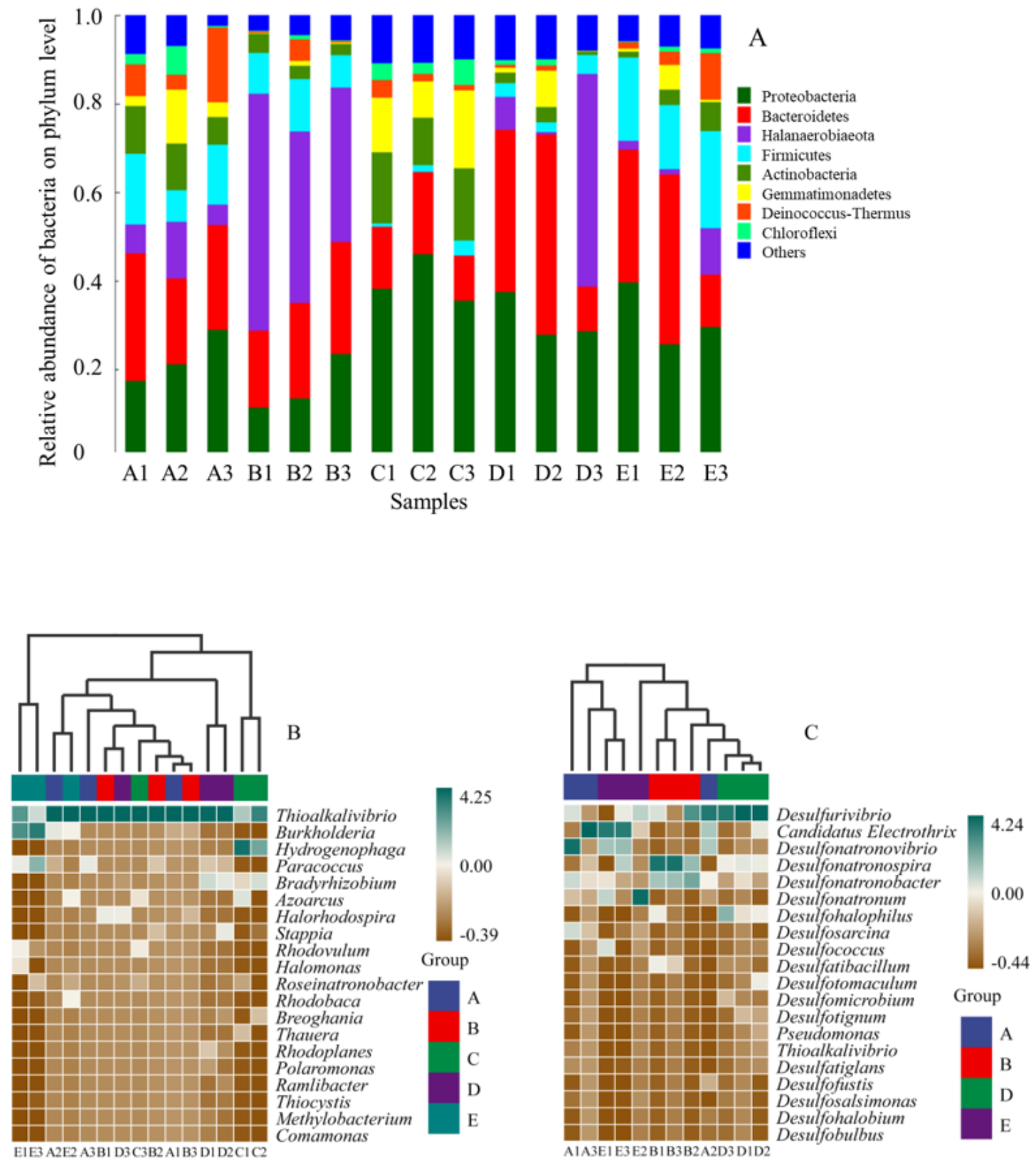

\section{Figure 2}

$<$ p>Microbial community structures in soda lakes. (A) Total bacteria on phylum level, (B) SOB on genus level, (C) SRB on genus level. Note: Due to the technical error, the extraction of $<\mathrm{em}>\mathrm{dsr}</ \mathrm{em}>\mathrm{B}$ gene from the lake $\mathrm{C}$ sediment samples was not completed. Thus, the $<\mathrm{em}>\mathrm{dsr}</ \mathrm{em}>\mathrm{B}$ gene sequencing results derived from four lakes were analyzed. $</ \mathrm{p}>$ 

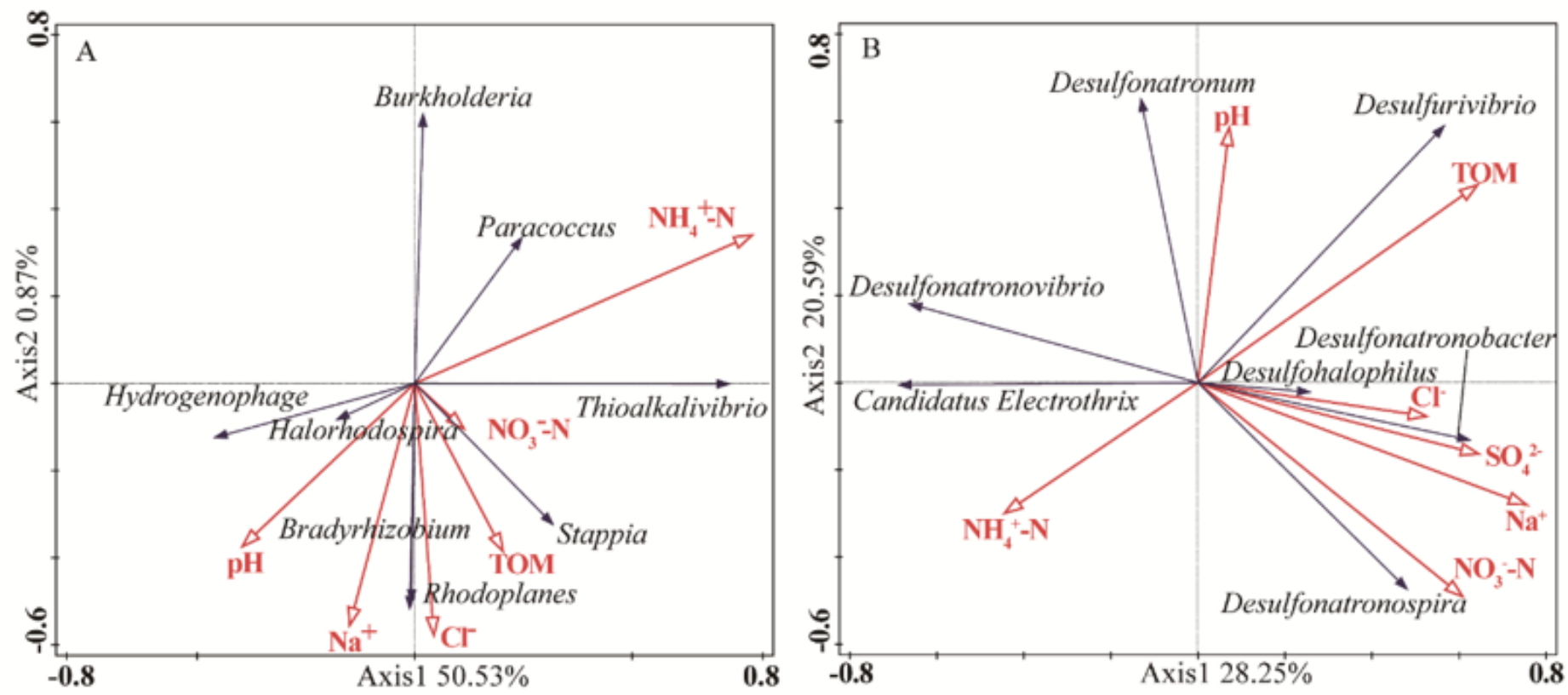

Figure 3

$<p>$ Redundant analysis (RDA) of the distribution of dominant genera with respect to physicochemical characteristics. The purple arrows represent the bacterium, and the red arrows denote the physicochemical characteristics. Arrow vector length corresponds to the strength of the correlation with the axes. (A, SOB; B, SRB). $</ p>$

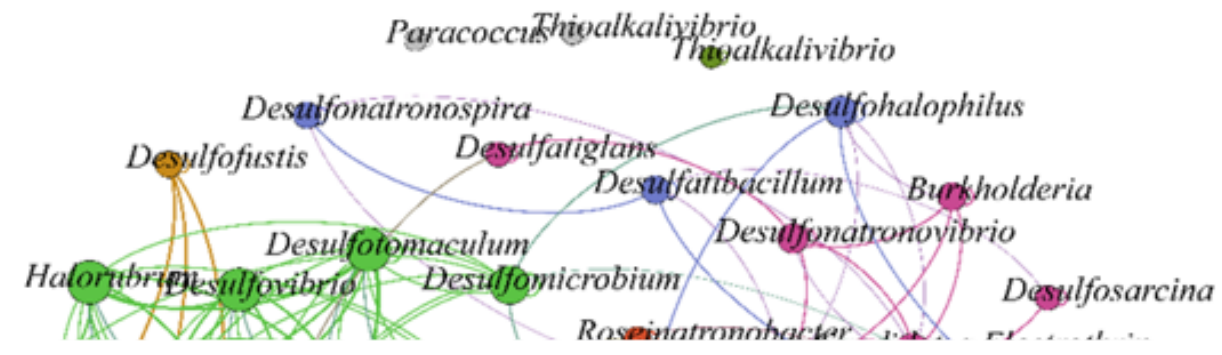


Figure 4

$<p>$ Network diagram of bacterial groups associated with sulfur cycle. $</ p>$

\section{Supplementary Files}

This is a list of supplementary files associated with this preprint. Click to download.

- Supplementarymaterial20211202.docx 